any time between about 30 and 40 rears of age. The evidence afforded by the parasagittal ridge on the left parietal, by the meningeal grooves, and by the positions occupied by the fragments of the lambdoid suture upon the occipital and parietal fragments, corroborates the correctness of this identification of the median plane.

\title{
OORIESPONDEINOE.
}

\section{THE FREEZING OF SURFACE SOIL.}

SrR,-In Nature for 1911 I described the occurrence of tooth-like projections of fibrous ice which formed on exposed pieces of chalk partly buried in the soil. Here the water had not frozen in the chalk but on the surface, fresh supplies of water coming from below through the capillaries of the stone to freeze at the surface. Each pore would seem to have produced a separate crystal fibre, the fibres from each pore adhering to one another and resembling fibrous gypsum in appearance. Occasionally when the supply of water from below varied over the chalk surface, strains were set up by the irregular growth of the 'ice-teeth', which caused the mass to split along the fibres and grow in spiral forms. The amount of ice produced was several times greater than the rolume of the chalk upon which it formed, showing that the water had passed from the wet ground through the chalk and frozen on the surface.

Since describing the above I have seen a "Note on the action of Frost on Soil", by Milner Roberts, in the Journal of Geology, vol. xi, pp. 314-17. He says, "The action of frost in altering the surface of the soil was well shown during the period of cold weather which prevailed over the Puget Sound district from February 10 to 18, 1903.

"The first night's frost had its usual effect of raising the surface of loose ground, which was well illustrated by gravelly soil. A layer of ice consisting of vertical prisms five-eighths of an inch long formed during the night at a depth of about five-eighths of an inch below the surface, thus raising the overlying material without otherwise disturbing it. The cold of the following night produced a similar layer of ice almost an inch thick below the first one, raising the latter along with its load of sand and gravel.

"The following conditions prevailed and seem to have controlled the formation of these many storied forms: (1) ground which was not frozen and which was readily permeable to moisture ; (2) freezing temperature at night; (3) mild thawing in the daytime; and (4) considerable moisture in the soil."

During the present week similar conditions have prevailed here, and similar effects have been produced on a gravel walk. In the Figure, p. 96, which is full size, $a$ and $b$ are two layers of fibrous ice resting upon wet clayey soil $d$. During the first night's frost the pebbles and some soil were lifted. On the following night the laser of ice $b$ was formed. It, however, raised with it a thin layer of soil $c$. Particles of soil were scattered throughout the ice, having been detached from the soil below and lifted by the growing ice fibres. 
This growth of ice was not regular over the whole surface, for here and there pits and grooves were left in the gravelly surface. Examination also showed that there were numerous cavities $e$ in the fibrous ice layers, resulting from the local failure of the water supply from below.

The segregation of the water to form ice layers when the surface of the ground freezes not only seems to have a bearing upon the question of the flow of the frozen soil-cap downhill, but also serves to explain the peculiar arrangement of the stones at or near the surface, especially in high latitudes. It has been remarked by many that in frigid climates the stones and other objects on the ground stand with their longer axes in a vertical position.

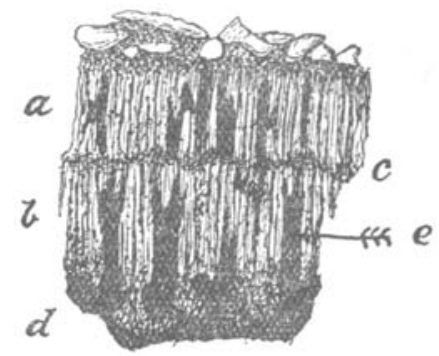

During the melting of the ice layers below the surface stones would subside irregularly, slipping on end into the cavities and channels formed by the melting of the ice below. When it is remembered that the formation of ice layers beneath the surface and their melting must take place very frequently in high latitudes, the positions of the stones near the surface must be moved with regard to each other very often. In this movement we have a cause which appears to be capable of producing the peculiar vertical arrangement of the stones near the surface.

Such a vertical arrangement of the longer axes of the stones may be seen in the upper surfaces of many of the high-level river gravel terraces of England, but not in the lower gravels. It is common in the high-level river gravel terraces of the Trent, where signs of disturbance often extend downwards many feet from the surface.

R. M. DeEley.

\section{MISOEIIANEOUS.}

Munificent Bequests in aid of Science.-Dr. Tempest Anderson, who died on board ship in the Red Sea on August 26 last year, has left $£ 50,000$ to the Yorkshire Philosophical Society, of which he was formerly president; and $£ 25,000$ to the Percy Sladen Memorial Fund, established by his sister, Mrs. Sladen, in 1904.

Geologicar Surver.- The President of the Board of Education has promoted Mr. G. W. Lamplugh, F.R.S., to the post of Assistant Director (for England and Wales) on the Geological Survey of Great Britain, and Mr. T. C. Cantrill to that of District Geologist. The appointments took effect on January 6, 1914. 